\title{
AC 2007-342: FACULTY REWARD SYSTEM REFORM FOR ADVANCEMENT OF PROFESSIONAL ENGINEERING EDUCATION FOR INNOVATION: REVISITING THE URGENCY FOR REFORM
}

\section{Dennis Depew, Purdue University}

DENNIS R. DEPEW is dean of the college of technology, Purdue University.

\section{Gary Bertoline, Purdue University}

GARY R. BERTOLINE is professor and assistant dean for graduate studies of the college of technology, Purdue University.

Mark Schuver, Purdue University

MARK T. SCHUVER is director of the Rolls-Royce-Purdue Master's degree program, Purdue University.

Donald Keating, University of South Carolina

DONALD A. KEATING is associate professor of mechanical engineering, University of South Carolina, and chair ASEE-Graduate Studies Division.

\section{Thomas Stanford, University of South Carolina}

THOMAS G. STANFORD is assistant professor of chemical engineering, University of South Carolina.

\section{Duane Dunlap, Western Carolina University}

DUANE D. DUNLAP is professor, interim dean, Kimmel School, Western Carolina University, and program chair ASEE-Graduate Studies Division. 


\section{Faculty Reward System Reform for Advancement of Professional Engineering Education for Innovation: Revisiting the Urgency for Reform}

\section{Introduction}

This is the first of three invited papers prepared for a special panel session of the National Collaborative Task Force on Engineering Graduate Education Reform to enable a strong U.S. engineering workforce for competitiveness and national security. Initiated in 2000 by the ASEEGraduate Studies Division, College Industry Partnership Division, and Corporate Members Council, the National Collaborative Task Force is a coalition of key leaders from innovative universities and industry who are working in a unique collaboration to respond to the urgency for reshaping the U.S. system of engineering graduate education to better serve the needs of modern engineering practice to strengthen the nation's capability for technology development and innovation.

The National Collaborative is focusing on two primary questions:

- First, can an effective system of professional engineering graduate education be created in the United States for developing our engineering talent in industry so that the continuing future of engineering practice for creative technology development $\&$ innovation in this country may be assured for economic competitiveness and national security purposes?

- Second, how can this system of professional engineering graduate education be implemented across the United States using the combined resources of universities and industry to ensure world-class engineering leadership for innovation so that each state and region can prosper over the long-term?

This paper looks primarily at the second question as it seeks answers to how faculty will be rewarded in a system where teaching professionals is as important as research. The need for reform to design a new faculty reward system as a complement to the traditional researchoriented faculty reward system for advancement of professional engineering education for innovation is no longer in question. However, little has changed at most universities, with a few notable exceptions, across the nation. Today, leading universities must be more responsive to their multi-faceted missions and provide more engagement in the professions.

One major responsibility of the responsive university in the $21^{\text {st }}$ century is advanced professional graduate education for the engineering profession. This responsibility includes the creation of an appropriate faculty reward system for professionally-oriented faculty within graduate centers who are helping to further educate the nation's engineers as leaders, creators, and innovators of technological advancement in advanced engineering practice in industry. As the overview paper in this session, this first paper revisits the need for faculty reward reform for professionallyoriented faculty at the nation's colleges of engineering and technology and sustains the vision for moving professional graduate education forward in the national interest to ensure a strong U.S. engineering workforce for competitiveness and national security purposes. 


\section{Discussion}

There is a large and growing need for the advancement of professional education for the nation's engineers in industry. There is an especially critical need to develop engineers as 'champions', 'innovators', and 'leaders' throughout their professional careers through professionally-oriented graduate studies. This need is so large that it is not out of the question to consider creating academic departments [graduate centers] within existing colleges of engineering and technology that cater solely to the professional graduate degrees. These "professional studies departments" [graduate centers] would have their own administrative structure, leadership, and faculty whose primary mission is to develop and provide high-quality professional graduate education for engineers within statewide regional industry. The graduate centers would develop professional curricula that could be delivered in the traditional manner through courses on campus but would also develop professional degree programs that could be delivered by distance or through a hybrid approach of classes on campus a few times a semester as well as by distance, and on-site in industry.

The faculty would be comprised of experienced professionals that are hired as full-time faculty. The full-time faculty would be tenure track that would be evaluated and promoted based on their efforts to create and deliver courses and to advance the practice of engineering through meaningful creative scholarship. In addition, they would be expected to be active in the scholarship of professional graduate education by presenting papers, writing journal articles to improve professional education and to engage in creative scholarship that advances the practice of engineering for creative technology development $\&$ innovation. This scholarly effort along with their performance in the classroom and curriculum development would be the basis for their promotion and tenure.

Additional faculty may be needed to deliver the curricula so these departments [graduate centers] would hire adjunct faculty to assist with the delivering of the courses. Adjunct faculty would primarily be expert practicing professionals from industry. Others could be recent retirees who have many years of experience as a professional engineer or technologist.

The "professional studies department" [graduate center] would be revenue generating because most of the curriculum will be delivered by distance or through special hybrid programs that fall outside the traditional on campus graduate programs. The revenue generated would be used to supplement the recurring funds from the university to hire adjunct faculty, deliver courses by distance, recruit students and travel to companies to promote the program, and supplement the recurring funds of the full-time faculty. The revenue could also be used to provide support for the creative scholarly activities engaged in by the full-time faculty and to create fellowships to recruit outstanding creative students, supplement the tuition for needs-based students, and to diversify the student body.

Professional studies may also be integrated into existing forward thinking academic structures by integrating the activities into traditional academic department or through existing distance education efforts and continuing education departments. Whichever course is followed there will be similar challenges and opportunities. By integrating professional graduate education into a traditional academic department there will be challenges related to the different needs and 
expectations between the professional studies faculty and those engaged in the more traditional academic role of research-oriented faculty. By integrating professional graduate education into distance learning programs or continuing education, there are challenges related to recruiting and compensating faculty capable of developing and delivering professional graduate education. By creating new units and separating professional graduate education from traditional researchoriented academic departments a number of risks result but benefits also result to allow professional education to reach its full potential on the nation's campuses.

Whichever path is chosen regarding the development and provision of professional graduate education for the nation's engineers, there are several issues that must be addressed to attract and retain professionally-oriented faculty who will be required to develop the professional curricula, educate professionals, and sustain the program:

$>$ Current compensation for professionally oriented faculty in university non-tenure track positions is significantly less than comparable positions in industry $(1 / 2$ to 1/3). Base salary increases and the opportunity for performance based, periodic increases are required.

$>\quad$ Incentives to attract and retain high quality, experienced, professional faculty to colleges of engineering and technology must be created.

$>$ Consider introducing performance based bonus options. Examples might include goals for achieving additional revenue from tuition or fee based programs. Other options would be to compensate for teaching on weekends or off-campus using overtime pay. The key is to identify goals that the faculty can take ownership for.

$>\quad$ Offering full medical and pension benefits would also provide additional incentive.

$>\quad$ Most professionals understand and accept the concept of pay for performance. Establishing a structure with clear measures and established accountability which leads to corresponding compensation increases will motivate these potential faculty members.

$>\quad$ Other, more subtle areas to consider are the importance of clean, modern facilities (offices and classrooms) with access to the latest technology tools for teaching.

$>$ Flexible schedules are very important to most professionals as they contrast the environment of the academic world to the corporate world.

These alternatives can be funded by the professional education programs and should be built into the budget when developing a business case which would be reflected in the tuition paid by students.

Since not all faculty will buy into the "pay for performance" concept, it should be voluntary and the result of targeted recruiting for professional graduate education.

A training program for faculty long on content knowledge and experience but short on teaching skills must be established. This should also include a mentor relationship with a tenured or tenure track faculty member whom is also invested in professional graduate education. 


\section{Conclusions}

There are a number of challenges facing any institution that decides to offer professional graduate education for the nation's engineers. However, there are many opportunities that far outweigh the risks. As academic leaders in engineering and technology we must address the critical need in our society to prepare and sustain the further growth of engineers to meet the growing needs of this country, to stay competitive, and to continue our preeminence for leadership of the creation, development, and innovation of new technology. This is a challenge we must meet and the alternative methods to meet this challenge as addressed in this paper we hope can serve as a guide.

\section{Bibliography}

1. Council on Competitiveness, Innovate America, 2005.

2. Council on Competitiveness, http://www.compete.org, 2006.

3. Committee on Science, Engineering, and Public Policy (COSEPUP), Reshaping the Graduate Education of Scientists and Engineers, National Academy Press, 1995.

4. Bush, V., Science: The Endless Frontier, 1945.

5. Wulf, W. A., The Urgency of Engineering Education Reform, Main Plenary Address, Proceedings American Society for Engineering Education Annual Conference, 2002.

6. National Academy of Engineering, Technically Speaking, 2002.

7. National Academy of Engineering, Educating the Engineer of 2020: Phase I Report, 2004.

8. National Academy of Engineering, Educating the Engineer of 2020: Phase II Report, 2005.

9. Bertoline, G. R., Depew, D. R., Dyrenfurth, M. J., McHenry, A. L., DeLoatch, E. M., Lee, P. Y., Dunlap, D. D., Tricamo, S. J., Keating, D. A., Stanford, T. J. (2005). A Look at Representative Templates for Professionally Oriented Faculty Reward Systems in Other Service Professions. 2005 ASEE Conference, Portland, OR. 